\title{
A promising novel biomarker for embryogenesis and carcinogenesis: S100P protein
}

\author{
Uzay Gormus
}

Division of Biochemistry; Department of Medical Biochemistry and Biophysics, Karolinska Institute, Stockholm, Sweden

\begin{abstract}
Objectives: Over the past decade, many great improvements have been achieved in cancer detection. Although there are many cancer biomarkers in use, unfortunately most of these biomarkers cannot yet be used efficiently for clinical purposes. Novel and reliable biomarkers are still required for the early detection and prognosis prediction of cancer. In many aspects, S100 calcium-binding protein P (S100P), a protein that is encoded by the S100P gene, is an interesting and promising marker that can enable the detection of many aggressive cancers in the early stages. S100P overexpression seems to be related to cancer aggression because of its capability to promote cell proliferation, invasion, and migration. Once we understand the molecular mechanisms better, S100P may be used as a specific biomarker and even a potential drug target for various cancers. The S100P protein is discussed in this review in relation to its functions and possible usage in the clinical area, mainly focusing on potential use in cancer research.
\end{abstract}

Keywords: Biomarker, cancer, S100P, tumor

$S_{i n}^{100}$ 100 calcium-binding protein $\mathrm{P}(\mathrm{S} 100 \mathrm{P})$, is a member of an interesting family, the $S 100$ family of proteins. It is useful to start with some general information about the family, because it appears that there are thought-provoking and often interrelated functions.

\section{S100 protein family}

The $\mathrm{S} 100$ family is a family of proteins with a high degree of structural similarities; they are a small, dimeric, EF-hand (calcium-binding helix-loop-helix domains) superfamily of calcium-binding proteins that has also been shown to bind to other divalent metal ions, like $\mathrm{Mg}^{2+}, \mathrm{Cu}^{+2}, \mathrm{Mn}^{+2}$, and $\mathrm{Zn}^{+2}$ [1-3]. The name was a result of their solubility in $100 \%$ saturated ammonium sulphate [4]. There are currently 25 known members of the S100 family, which are tissue-specific $[2,5,6]$.

This protein family has important intracellular and extracellular roles. Some of these proteins have been determined to play a critical role in the immune system and tissue repair, while others have been found to have a role in neuroprotection after brain injuries $[7,8]$.

Extracellular S100 proteins function through interacting with various cell-surface receptors, but predominantly with receptors for advanced glycosylation end products (RAGE) and/or the toll-like receptor-4 (TLR4) $[9,10]$. Both receptors are known to be associated with immune inflammatory responses and tissue repair $[11,12]$. Many S100 proteins, such as the S100B and S100A sub-groups, have been suspected to have both pro- and anti-tumorigenic functions in various cancers [13-18].

\section{S100P protein}

\subsection{General information about S100P protein}

$\mathrm{S} 100 \mathrm{P}$ is a $10.4 \mathrm{kDa}, 95$-aminoacid residue, calcium-binding protein; it has $2 \mathrm{EF}$-hands, 1 with low affinity for calcium and 1 with high affinity. S100P has to be homodimeric for proper functioning [19]. Calcium-binding enables and activates its

Address for correspondence: Uzay Gormus, MD. Department of Medical Biochemistry and Biophysics, Karolinska Institute, Division of Biochemistry, Stockholm, Sweden

Phone: +90 5055670884 E-mail: druzay@gmail.com ORCID: 0000-0002-3124-0184

Accepted Date: December 05, 2018 Available Online Date: December 12, 2018 Available Online Date: January 15, 2019

${ }^{\circ}$ Copyright 2018 by International Journal of Medical Biochemistry - Available online at www.internationalbiochemistry.com

OPEN ACCESS This work is licensed under a Creative Commons Attribution-NonCommercial 4.0 International License. 
interactions with other proteins [1, 20]. Interestingly, S100P is only found in vertebrate species; it seems to be an evolutionarily young protein. The gene is also missing in rodents, with the exception of a few, such as the Norwegian rat and the opossum. S100P gene maps are found on the fourth chromosome (4p16) in humans. The S100P gene is known to have transcription factor binding sites for abscisic acid-responsive element binding protein 6 , nuclear factor-KB (NF-KB), NF-KB1, and globin transcription factor binding protein 3 [21].

The S100P protein, since its discovery in 1992, has been studied for its roles in human embryonic development and implantation, as well as its important functions in ordinary tissue and cancer. It is thought to be a potential diagnostic and therapeutic target. The " $p$ " in the name reflects the location of its first isolation, the placenta. Expression of the S100P protein is 90 - to 200-fold higher in the placenta than in any other organ $[22,23,20]$. As might be expected, it is predominantly expressed in the early stages of gestation during placental formation, and this high level of expression continues through the first trimester of pregnancy/ It is reduced by $50 \%$ during the second and third trimesters of gestation $[22,24]$. S100P has been clearly demonstrated to be an important regulator of trophoblast invasion during placentation [22, 24-26]. Interestingly, it was suspected that S100P was more dramatically related to cell invasion than cell migration. But obviously, both are affected by reducing S100P expression, and significant changes in motility and migration distances were detected, as well as a very dramatic reduction in invasion [22].

Proper migration and invasion of trophoblast cells into the maternal endometrial decidua and myometrium is tremendously important; therefore, this protein has mainly been studied for its relationships with implantation success, miscarriages, and fetal growth restriction. An increased level correlates with progesterone stimulation [27].

In healthy adult tissues, the highest S100P transcript levels have been observed in the early stages of differentiation in the esophageal epithelium, and a moderate level of expression has been detected in the stomach, duodenum and large intestine, prostate, trachea, bone marrow, and leukocytes [28]. At the protein level, the highest S100P levels have been detected in the stomach and placenta [29].

The S100P protein is mainly cytoplasmic and but seems to also be found in blood circulation. It has some membrane receptors, such as RAGE, which can be used in an autocrine manner, and this interaction is thought to be promising for future therapeutic strategies [30,31].

\subsection{Significance of S100P}

S100P expression has been observed within the uterine wall during rhythmic hormonal fluctuations, and so it was intensively investigated in embryo implantation studies. During the implantation period, S100P expression may increase approximately 100 times beyond the other phases of the menstrual cycle [32-34]. It has been considered that S100P could be a po- tentially unique biomarker of a receptive endometrium, but how S100P might encourage implantation is still unknown.

It was also discovered that S100P was expressed in various tissues during embryonic development. The expression of S100P was intense in the developing urethra, bladder, renal pelvis, developing glomerulus, spleen, and gastrointestinal tract in various stages of embryogenesis [35].

There are many currently known molecular links between the regulation of normal embryogenesis and the induction of cancer; S100P seems to be one of the proteins with roles in both embryogenesis and cancer mechanisms. There are several studies of S100P in different cancer types and it seems to be related to a poor prognosis; S100P is one of the important proteins thought to be related to metastasis. The majority of published reports describe the role of S100P in diverse human cancers, where it is increasingly recognized as a potential diagnostic and therapeutic target; however, the molecular mechanisms have not yet been defined in detail.

It seems that after binding with calcium ions, each S100P protein gains the capacity to form dimers, which are the active form of the protein, and this triggers a confirmation to bind with other proteins [36-39]. The secreted form of this dimer has autocrine and paracrine functions as it interacts with various kinds of receptors, such as RAGE, which can lead to aberrant cell proliferation and malignant transformation $[30,40,41]$.

The expression of $5100 \mathrm{P}$ is known to be influenced by several hormones; it is up-regulated in the presence of androgens, as well as progesterone, retinoic acid, bone morphogenic protein-4, and glucocorticoids [42-46].

\subsection{S100P, cancer, and metastasis}

It is not a surprise to observe similarities between embryogenesis and carcinogenesis; there are many known molecular links between the regulation of normal embryo development and the induction of cancer. Both have high rates of cell division and cell migration. There are many molecules that are critical for embryonic development and also play a role in the development or alteration of tumors. Important genes that have been identified as important in embryonic development are also active during cancer development. Therefore, it seems that once we understand the behaviors of embryonic cells in terms of division, differentiation, and migration mechanisms, it may be possible to control the "uncontrollable" cancer cells.

S100P protein overexpression has been detected in several malignancies, including breast, colon, prostate, lung, and pancreatic cancers. S100P appears to be a molecule that is important in both embryogenesis and carcinogenesis, particularly by stimulating the invasiveness and motility of aggressive cells [47-49]. S100P expression has been linked to the progression of malignant cells originating from various tissue sources, including the pancreas, lung, colon, and breast [50-62]. Due to its expression in neoplastic lesions and absence in most healthy tissues, S100P has been evaluated both as a potential 
biomarker for the detection of several cancers and also as a cause of aggressivity and metastasis.

There are several studies investigating the role of the S100P protein in cancer and metastasis because high levels of S100P expression have been found in a variety of tumor types, such as breast cancer, esophageal cancer, cholangiocarcinoma, cervical cancer, endometrial cancer, colon cancer, ovarian cancer, and pancreatic adenocarcinoma, which are all aggressive cancers $[17,46,57,59,63-65]$.

As a family, the $\mathrm{S} 100$ proteins have been shown to bind to the tetratricopeptide repeat proteins. Recently, S100P was demonstrated to contribute to the degradation of important heat shock proteins, like as Hsp70, Hsp90, and even mutated p53, and so it is thought to be important both in the stress response and in oncogenesis [66].

$\mathrm{S100P}$ is also known to be related to cell adhesion and involved in transducing cellular signaling pathways by interacting with important proteins, such as IQGAP1, ezrin, and integrins, and affecting microtubule dynamics, cell-to-cell contacts, and cell proliferation and transformation, motility, and invasion [67-69]. Several signal pathways were evaluated in order to further illuminate the molecular mechanisms of S100P, and it was shown to promote the phosphorylation of extracellular signal-regulated kinase (ERK) and Janus $\mathrm{N}$-terminal kinase, and it was assessed as an important element of the mitogen-activated protein kinase pathway, rather than affecting their protein expression levels [69]. Its receptor, RAGE, increased, but beta-catenin expression was downregulated after S100P transfection [69-71]. It was also observed that S100P stimulated proliferation through p-ERK, p38, and NF-KB activation, but decreased apoptosis through Bcell lymphoma-extra large upregulation [69].This may indicate that S100P mainly has roles in bypassing cell apoptosis and increasing the percentage of G1-phase cells. It may cause high proliferation without control.

In addition to its suspected activity in tumor proliferation and invasion, S100P overexpression seems to also be associated with drug resistance in various cancers [58-60], and it may be especially important alongside some commonly used drugs, such as 5 -fluorouracil, methotrexate, cyclophosphamide, and etoposide.

\section{Conclusion}

S100P protein is an interesting protein to be further investigated. Additional examination of the molecular mechanisms related to this protein may enable us to solve many problems in embryonic implantation, tissue regeneration, and oncology. Especially in the area of cancer research, further experiments and clinical follow-up studies should be conducted to identify specific targets of S100P that have oncogenic functions. S100P is a promising biomarker for use in the detection of aggressive cancers in early invasive stages and/or relapse. Since an abnormally high S100P level might be a major driving factor responsible for a poor prognosis, it may be used as a prognostic marker, or even a marker to detect possible drug resistance. There are still many aspects of this protein to be explored and interpreted.

\section{Conflict of interest: None declared.}

Financial Disclosure: None declared.

Peer-review: Externally peer-reviewed.

\section{References}

1. Donato R. S100: a multigenic family of calcium-modulated proteins of the EF-hand type with intracellular and extracellular functional roles. Int J Biochem Cell Biol 2001;33:637-68.

2. Gribenko A, Lopez MM, Richardson JM 3rd, Makhatadze GI. Cloning, overexpression, purification, and spectroscopic characterization of human S100P. Protein Sci 1998;7:211-15.

3. Gilston BA, Skaar EP, Chazin WJ. Binding of transition metals to S100 proteins. Sci China Life Sci 2016;59:792-801. [CrossRef]

4. Moore BW. A soluble protein characteristic of the nervous system. Biochem Biophys Res Commun 1965;19:739-44. [CrossRef]

5. Bresnick AR, Weber DJ, Zimmer DB. S100 proteins in cancer. Nat Rev Cancer 2015;15:96-109. [CrossRef]

6. Li F, Men X, Zhang W. S100 protein in breast tumor. Indian J Cancer 2014;51:67-71. [CrossRef]

7. Boteanu RM, Suica VI, Uyy E, Ivan L, Dima SO, Popescu I, et al. Alarmins in chronic noncommunicable diseases: atherosclerosis, diabetes and cancer. J Proteomics 2016;153:21-9.

8. Dmytriyeva O, Pankratova O, Owczarek S, Sonn K, Soroka $\mathrm{V}$, Ridley CM, et al. The metastasis-promoting S100A4 protein confers neuroprotection in brain injury. Nat Commun 2012;3:1197. [CrossRef]

9. Donato R, Cannon BR, Sorci G, Riuzzi F, Hsu K, Weber DJ, et al. Functions of S100 proteins. Curr Mol Med 2013;13:24-57.

10. Bertheloot D, Latz E. HMGB1, IL-1a, IL-33 and S100 proteins: dual-function alarmins. Cell Mol Immunol 2016;14:43-64.

11. Ramasamy R, Yan SF, Herold K, Clynes R, Schmidt AM. Receptor for advanced glycation end products: fundamental roles in the inflammatory response: winding the way to the pathogenesis of endothelial dysfunction and atherosclerosis. Ann $\mathrm{N}$ Y Acadof Sci 2008;1126:7-13. [CrossRef]

12. Sorci G, Riuzzi F, Giambanco I, Donato R. RAGE in tissue homeostasis, repair and regeneration. Biochim Biophys Acta 2013;1833:101-9. [CrossRef]

13. Hartman KG, McKnight LE, Liriano MA, Weber DJ. The evolution of S100B inhibitors for the treatment of malignant melanoma. Future Med Chem 2013;5:97-109. [CrossRef]

14. Aishima S, Fujita N, Mano Y, Kubo Y, Tanaka Y, Taketomi A, et al. Different roles of $5100 \mathrm{P}$ overexpression in intrahepatic cholangiocarcinoma: carcinogenesis of perihilar type and aggressive behavior of peripheral type. Am J Surg Pathol 2011;35:590-8.

15. Winningham-Major F, Staecker JL, Barger SW, Coats S, Van Eldik LJ. Neurite extension and neuronal survival activities of recombinant $\mathrm{S} 100$ beta proteins that differ in the content and position of cysteine residues. J Cell Biol 1989;109:3063-71.

16. Charmsaz S, Hughes É, Bane FT, Tibbitts P, Mcllroy M, Byrne C, 
et al. $\mathrm{S} 100 \beta$ as a serum marker in endocrine resistant breast cancer. BMC Med 2017;15:79. [CrossRef]

17. Guo L, Chen S, Jiang H, Huang J, Jin W,Yao S. The expression of S100P increases and promotes cellular proliferation by increasing nuclear translocation of beta-catenin in endometrial cancer. Int J Clin Exp Pathol 2014;7:2102-12.

18. Donato R, Sorci G, Giambanco I. S100A6 protein: functional roles. Cell Mol Life Sci 2017;74:2749-60. [CrossRef]

19. Koltzscher M, Gerke V. Identification of hydrophobic amino acid residues involved in the formation of S100P homodimers in vivo. Biochemistry 2000;39:9533-9. [CrossRef]

20. BeckerT, Gerke V, Kube E, Weber K. S100P, a novel Ca(2+)-binding protein from human placenta. cDNA cloning, recombinant protein expression and $\mathrm{Ca} 2+$ binding properties. Eur J Biochem 1992;207:541-7. [CrossRef]

21. Zimmer DB, Eubanks JO, Ramakrishnan D, Criscitiello MF. Evolution of the $\mathrm{S} 100$ family of calcium sensor proteins. Cell Calcium 2013;53:170-9. [CrossRef]

22. Tabrizi MEA, Lancaster TL, Ismail TM, Georgiadou A, Ganguly A, Mistry JJ, et al. S100P enhances the motility and invasion of human trophoblast cell lines. Sci Rep 2018,8:11488.

23. Emoto $Y$, Kobayashi R, Akatsuka H, Hidaka H. Purification and characterization of a new member of the $\mathrm{S}-100$ protein family from human placenta. Biochem Biophys Res Commun 1992;182:1246-53. [CrossRef]

24. Zhu HY, Wang JX, Tong XM, Xue YM, Zhang SY. S100P regulates trophoblast-like cell proliferation via P38 MAPK pathway. Gynecol Endocrinol 2015;31:796-800. [CrossRef]

25. Zhou T, Wang H, Zhang S, Jiang X, Wei X. S100P is a potential molecular target of cadmium-induced inhibition of human placental trophoblast cell proliferation. Exp Toxicol Pathol 2016;68:565-70. [CrossRef]

26. Zhu HY, Tong XM, Lin XN, Jiang LY, Wang JX, Zhang SY. Expression and Distribution of Calcium-Binding Protein S100P in $\mathrm{Hu}-$ man Placenta during Pregnancy. Int J Fertil Steril 2015;8:445-52.

27. Zhang D, Ma C, Sun X, Xia H, Zhang W. S100P expression in response to sex steroids during the implantation window in human endometrium. Reprod Biol Endocrinol 2012;10:106.

28. Sato N, Hitomi J. S100P expression in human esophageal epithelial cells: Human esophageal epithelial cells sequentially produce different S100 proteins in the process of differentiation. Anat Rec 2002;267:60-9. [CrossRef]

29. Parkkila S, Pan PW, Ward A, Gibadulinova A, Oveckova I, Pastorekova $S$, et al. The calciumbinding protein S100P in normal and malignant human tissues. BMC Clin Pathol 2008;8:2.

30. Arumugam T, Simeone DM, Schmidt AM, Logsdon CD. S100P stimulates cell proliferation and survival via receptor for activated glycation end products (RAGE). J Biol Chem 2004;279:5059-65. [CrossRef]

31. Fuentes MK, Nigavekar SS, Arumugam T, Logsdon CD, Schmidt AM, Park JC, et al. RAGE activation by S100P in colon cancer stimulates growth, migration, and cell signaling pathways. Dis Colon Rectum 2007;50:1230-40. [CrossRef]

32. Kodaman PH, Taylor HS. Hormonal regulation of implantation. Obstet Gynecol Clin North Am 2004;31:745-66. [CrossRef]
33. Wilcox AJ, Baird DD, Weinberg CR. Time of implantation of the conceptus and loss of pregnancy. N Engl J Med 1999;340:1796-9. [CrossRef]

34. Schäfer BW, Heizmann CW. The S100 family of EF-hand calcium-binding proteins: functions and pathology. Trends Biochem Sci 1996;21:134-40. [CrossRef]

35. Prica F, Radon T, Cheng Y, Crnogorac-Jurcevic T. The life and works of S100P - from conception to cancer. Am J Cancer Res 2016;6:562-76.

36. Cancemi P, Di Cara G, Albanese NN, Costantini F, Marabeti MR, Musso $\mathrm{R}$, et al. Large-scale proteomic identification of $\mathrm{S} 100$ proteins in breast cancer tissues. BMC Cancer 2010;10:476.

37. Tutar Y. Dimerization and ion binding properties of S100P protein. Protein Pept Lett 2006;13:301-6. [CrossRef]

38. Eckert RL, Broome AM, Ruse M, Robinson N, Ryan D, Lee K. S100 proteins in the epidermis. J Invest Dermatol 2004;123:23-33.

39. Streicher WW, Lopez MM, Makhatadze GI. Modulation of quaternary structure of S100 proteins by calciumions. Biophys Chem 2010;151:181-6. [CrossRef]

40. Gibadulinova A, Tothova V, Pastorek J, Pastorekova S. Transcriptional regulation and functional implication of S100P in cancer. Amino Acids 2011;41:885-92. [CrossRef]

41. Jiang $H$, Hu H, Tong $X$, Jiang $Q$, Zhu $H$, Zhang S. Calciumbinding protein S100P and cancer: mechanisms and clinical relevance. J Cancer Res Clin Oncol 2012;138:1-9. [CrossRef]

42. Averboukh L, Liang P, Kantoff PW, Pardee AB. Regulation of S100P expression by androgen. Prostate 1996;29:350-5.

43. Chandramouli A, Mercado-Pimentel ME, Hutchinson A, Gibadulinova A, Olson ER, Dickinson $S$, et al. The induction of S100p expression by the Prostaglandin E(2) (PGE(2))/EP4 receptor signaling pathway in colon cancer cells. Cancer Biol Ther 2010;10:1056-66. [CrossRef]

44. Shyu RY, Huang SL, Jiang SY. Retinoic acid increases expression of the calcium-binding protein S100P in human gastric cancer cells. J Biomed Sci 2003;10:313-9. [CrossRef]

45. Kino T, Manoli I, Kelkar S, Wang Y, Su YA, Chrousos GP. Glucocorticoid receptor (GR) beta has intrinsic, GRalpha-independent transcriptional activity. Biochem Biophys Res Commun 2009;381:671-5. [CrossRef]

46. Hamada S, Satoh K, Hirota M, Fujibuchi W, Kanno A, Umino $J$, et al. Expression of the calcium-binding protein S100P is regulated by bone morphogenetic protein in pancreatic duct epithelial cell lines. Cancer Sci 2009;100:103-10. [CrossRef]

47. Arumugam T, Simeone DM, Van Golen K, Logsdon CD. S100P promotes pancreatic cancer growth, survival, and invasion. Clin Cancer Res 2005;11:5356-64. [CrossRef]

48. Austermann J, Nazmi AR, Müller-Tidow C, Gerke V. Characterization of the Ca2+-regulated ezrin-S100P interaction and its role in tumor cell migration. J Biol Chem 2008;283:29331-40.

49. Zhou C, Zhong Q, Rhodes LV, Townley I, Bratton MR, Zhang $\mathrm{Q}$, et al. Proteomic analysis of acquired tamoxifen resistance in MCF-7 cells reveals expression signatures associated with enhanced migration. Breast Cancer Res 2012;14:R45.

50. Birkenkamp-Demtroder K, Olesen SH, Sørensen FB, Laurberg $S$, Laiho P, Aaltonen LA, et al. Differential gene expression in 
colon cancer of the caecum versus the sigmoid and rectosigmoid. Gut 2005;54:374-84. [CrossRef]

51. Bartling B, Rehbein G, Schmitt WD, Hofmann HS, Silber RE, Simm A. S100A2-S100P expression profile and diagnosis of non-small cell lung carcinoma: impairment by advanced tumour stages and neoadjuvant chemotherapy. Eur J Cancer 2007;43:1935-43. [CrossRef]

52. Wang G, Platt-Higgins A, Carroll J, de Silva Rudland S, Winstanley J, Barraclough R, et al. Induction of metastasis by S100P in a rat mammary model and its association with poor survival of breast cancer patients. Cancer Res 2006;66:1199-207.

53. Rehbein G, Simm A, Hofmann HS, Silber RE, Bartling B. Molecular regulation of S100P in human lung adenocarcinomas. Int J Mol Med 2008;22:69-77. [CrossRef]

54. Missiaglia E, Blaveri E, Terris B, Wang YH, Costello E, Neoptolemos JP, et al. Analysis of gene expression in cancer cell lines identifies candidate markers for pancreatic tumorigenesis and metastasis. Int J Cancer 2004;112:100-12. [CrossRef]

55. Maciejczyk A, Łacko A, Ekiert M, Jagoda E, Wysocka T, Matkowski $\mathrm{R}$, et al. Elevated nuclear S100P expression is associated with poor survival in early breast cancer patients. Histol Histopathol 2013;28:513-24.

56. Ohuchida K, Mizumoto K, Egami T, Yamaguchi H, Fujii K, Konomi $\mathrm{H}$, et al. S100P is an early developmental marker of pancreatic carcinogenesis. Clin Cancer Res 2006;12:5411-6.

57. Guerreiro Da Silva ID, Hu YF, Russo IH, Ao X, Salicioni AM, Yang $X$, et al. S100P calcium-binding protein overexpression is associated with immortalization of human breast epithelial cells in vitro and early stages of breast cancer development in vivo. Int J Oncol 2000;16:231-40. [CrossRef]

58. Basu GD, Azorsa DO, Kiefer JA Rojas AM, Tuzmen S, Barrett MT, et al. Functional evidence implicating S100P in prostate cancer progression. Int J Cancer 2008;123:330-9. [CrossRef]

59. Györffy B, Surowiak P, Kiesslich O, Denkert C, Schäfer R, Dietel $M$, et al. Gene expression profiling of 30 cancer cell lines predicts resistance towards 11 anticancer drugs at clinically achieved concentrations. Int J Cancer 2006;118:1699-712.

60. Diederichs S, Bulk E, Steffen B, Ji P, Tickenbrock L, Lang K, et al. S100 family members and trypsinogens are predictors of distant metastasis and survival in early-stage non-small cell lung cancer. Cancer Res 2004;64:5564-9. [CrossRef]

61. Sato N, Fukushima N, Matsubayashi H, Goggins M. Identification of maspin and S100P as novel hypomethylation targets in pancreatic cancer using global gene expression profiling. Oncogene 2004;23:1531-8. [CrossRef]

62. Dowen SE, Crnogorac-Jurcevic T, Gangeswaran R, Hansen M, Eloranta JJ, Bhakta V, et al. Expression of S100P and its novel binding partner S100PBPR in early pancreatic cancer. Am J Pathol 2005;166:81-92. [CrossRef]

63. Schor AP, Carvalho FM, Kemp C, Silva ID, Russo J. S100P calcium-binding protein expression is associated with high-risk proliferative lesions of the breast. Oncol Rep 2006;15:3-6.

64. Ji J, Zhao L, Wang X, Zhou C, Ding F, Su L, et al. Differential expression of $S 100$ gene family in human esophageal squamous cell carcinoma. J Cancer Res Clin Oncol 2004;130:480-6.

65. Zhi H, Zhang J, Hu G, Lu J, Wang X, Zhou C, et al. The deregulation of arachidonic acid metabolism-related genes in human esophageal squamous cell carcinoma. Int J Cancer 2003; 106:327-33. [CrossRef]

66. Mendillo ML, Santagata S, Koeva M, Bell GW, Hu R, Tamimi RM, et al. HSF1 drives a transcriptional program distinct from heat shock to support highly malignant human cancers. Cell 2012;150:549-62. [CrossRef]

67. Heil A, Nazmi AR, Koltzscher M, Poeter M, Austermann J, Assard $\mathrm{N}$, et al. S100P is a novel interaction partner and regulator of IQGAP1. J Biol Chem 2011;286:7227-38. [CrossRef]

68. Hsu YL, Hung JY, Liang YY, Lin YS, Tsai MJ, Chou SH, et al. S100P interacts with integrin alpha7 and increases cancer cell migration and invasion in lung cancer. Oncotarget 2015;6:2958598. [CrossRef]

69. Jiang $H$, Hu H, Lin F, Lim YP, Hua Y, Tong $X$, et al. S100P is Overexpressed in Squamous Cell and Adenosquamous Carcinoma Subtypes of Endometrial Cancer and Promotes Cancer Cell Proliferation and Invasion. Cancer Invest 2016;34:477-88.

70. Filipek A. S100A6 and CacyBP/SIP - two proteins discovered in ehrlich ascites tumor cells that are potentially involved in the degradation of beta-catenin. Chemotherapy 2006;52:32-4.

71. Matsuzawa SI, Reed JC. Siah-1, SIP, and Ebi collaborate in a novel pathway for beta-catenin degradation linked to p53 responses. Mol Cell 2001;7:915-26. [CrossRef] 